Sabet, S. A. H., Cam, A-M., \& Heaney, R. (2012). Share market reaction to the BP oil spill and the US government moratorium on exploration. Australian J ournal of Management, 37(1), 61-76

(c) The Author(s) 2012

This is pre-copy-editing, author-produced version of an article accepted for publication in Australian J ournal of Management, following peer review. The definitive published version (see citation above) is located on the article abstract page of the publisher, Sage.

This version was made available in the UWA Research Repository on the $5^{\text {th }}$ of November 2014 , in compliance with the publisher's policies on archiving in institutional repositories.

Use of the article is subject to copyright law. 


\title{
Share market reaction to the BP oil spill and the U.S. Government moratorium on exploration
}

\author{
Seyed Amir Hossein Sabet \\ RMIT University, Australia. \\ Marie-Anne Cam \\ RMIT University, Australia. \\ Richard Heaney \\ University of Western Australia, Australia.
}

\begin{abstract}
The shares of BP plc. and its subcontractors were rocked when the financial markets discovered the true impact of the Deepwater Horizon explosion as reported in the Wall Street Journal on 22 April 2010. While we track the impact of the disaster on share prices of the key participants, perhaps the most damaging response to the disaster was the introduction of the gulf oil exploration moratorium on deep water drilling. We find that this adversely affected a range of firms in the oil and gas industry, extending the economic impact of the disaster well beyond BP plc. and its subcontractors.
\end{abstract}

\section{Keywords}

BP oil spill, market efficiency, event study, U.S. Government intervention.

Corresponding Author: Richard Heaney, Faculty of Business, UWA Business School, Accounting and Finance, The University of Western Australia, 35 Stirling Highway, Crawley WA 6009. Email: Richard.Heaney@uwa.edu.au 


\section{Introduction}

The Deepwater Horizon oil platform, located in the Macondo Prospect in the Gulf of Mexico, caught fire on 20 April 2010 following an explosion. It eventually sank on the 22 April 2010. This disaster generated the largest marine oil spill recorded in U.S. history and it was not until 4 August 2010 before the leak was stopped. The environmental and political fallout from this disaster eventually resulted in other firms with gulf based oil extraction activities being embroiled in the disaster with the imposition by the Department of the Interior of a moratorium on deep water drilling in the gulf. Although the moratorium was challenged in the courts as being too broad, a revised moratorium relating specifically to deep-water wells that relied on a blowout preventer was announced on the 12 July 2010 and extended to 30 November 2010 . The moratorium, ultimately lifted on the 12 October 2010, appeared to be more a political response to the disaster than a carefully thought out regulatory response. Indeed, we find that the moratorium extended the costs of the disaster to a much wider group of oil and gas industry participants, not directly involved with the failure of the Deepwater Horizon rig.

While we analyse the share price movements of BP plc. and its sub-contractors, we also analyse the share price movements of portfolios of other oil and gas producers that focus on the gulf (moratorium firms) and a further portfolio of oil and gas producers with little direct interest in the gulf (other firms). This is a major contribution of the current paper, given the BP plc. focus of recent research in the area (Fodor and Stowe (2010 )). Our analysis focuses on the broader impact of the BP oil spill and the effect of attempts by the U.S. Government to introduce a moratorium following the spill. While many disasters documented in the literature exhibit rapid and unbiased share market reaction to announcement, this incident generated a series of share market shocks following the spill. For example, the introduction of the moratorium and the 
failed attempts to rectify the leak each added to the decline in the value of BP and its sub-contractors. An important issue from a policy viewpoint is the impact of the moratorium declared by the U.S. Department of the Interior. This moratorium resulted in a significant fall in the share price of those firms directly involved in the extraction of oil and gas in the gulf as well as an increase in crude oil prices at the time. While this paper focuses on the share price reaction it is important to also note the impact of the announcement on the crude oil price. The first moratorium was announced on the 27 May 2010 and the Cushing OK Crude Oil Future Contract 1 price rose from $\$ 71.51$ on the 26 May 2010 to $\$ 73.97$ on the 27 May 2010. This represents an increase of $4.25 \%$ across the 24 hour period including the announcement. This compares with an increase of $2.00 \%$ from the 20 April when the explosion took place through to 23 April 2010, the day after the BP oil spill was officially announced in the Wall Street Journal. It would appear that the crude oil price was more sensitive to the moratorium announcement than to the announcement of the BP spill. While the moratorium did not have a long-term impact we find it was nevertheless economically and statistically important for the share market. Figure 1 provides an indication of the movements in BP plc. share price over the BP oil spill period and highlights the loss of almost a third of the value BP plc. share price by September 2010.

A review of the literature is provided in the following section. Section 3 describes the data used in the study. The methodology used in the study is discussed in Section 4 and the results from analysis of the data are reported in Section 5. Conclusions are provided in Section 6.

\section{Literature review}

The environmental disaster literature tends to take one of two approaches, either a broad treatment of environmental disasters or an analysis of specific incidents and this paper falls into the latter group. Examples of broader analysis include disaster insurance 
(Froot (2001 )), supply of credit (Garmaise and Moskowitz (2009)), share market reaction to hazardous waste based incidents (Capelle-Blancard and Laguna (2010); Gupta and Goldar (2005); Laplante and Lanoie (1994); Lorraine, Collison and Power (2004); Muoghalu, Robinson and Glascock (1990 )), the impact of tropical storms (Fink, Fink and Russell (2010 )) and bank and insurance company operational loss events (Cummins, Lewis and Wei (2006 )). Other long-term studies focus on the

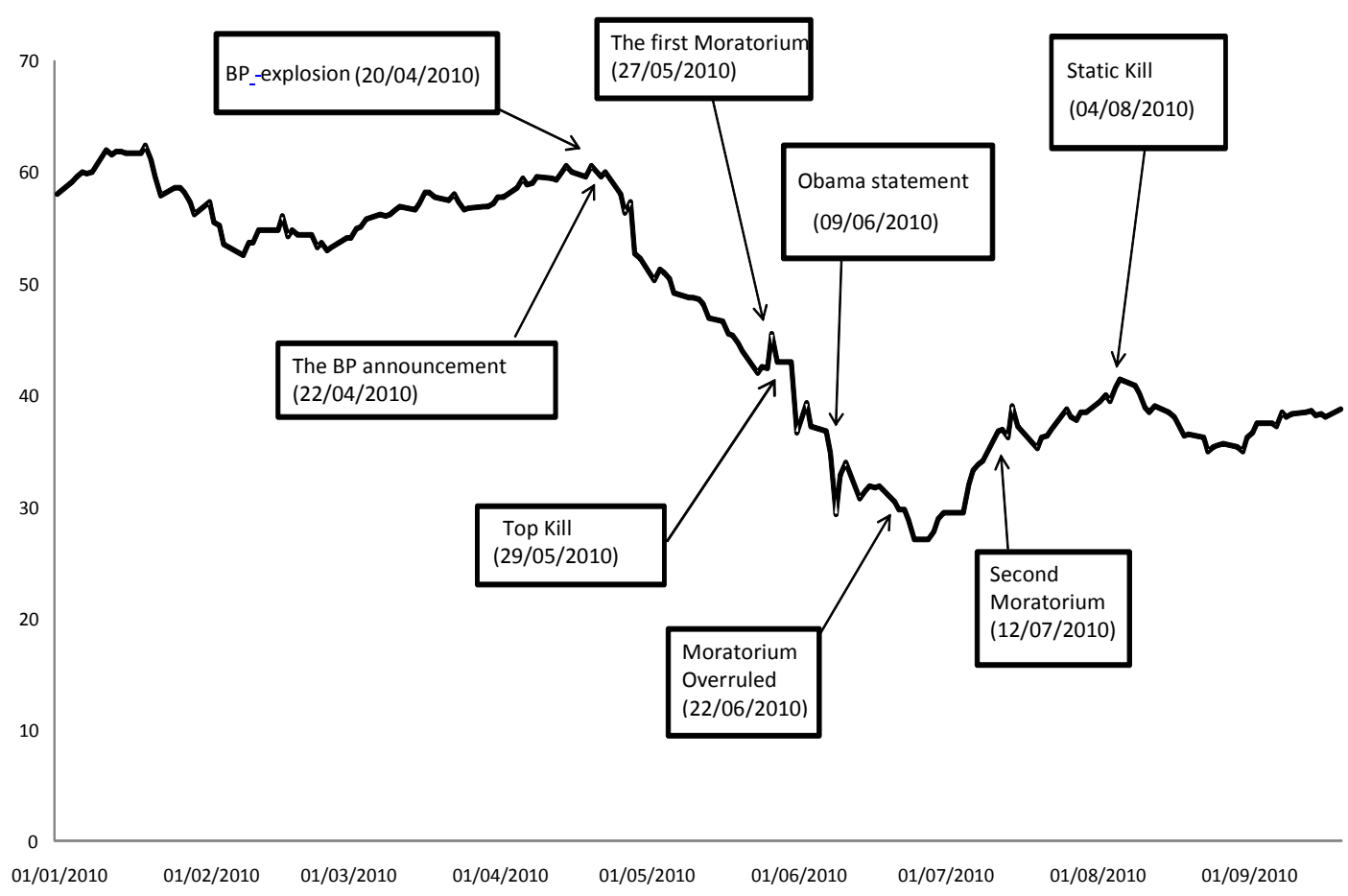

Figure 1 - BP plc. share price

This figure shows BP plc. daily share prices from 1 January 2010 to 15 September 2010 and significant dates following the BP oil spill explosion. 
impact of corporate social responsibility on firm performance (Choi, Kwak and Choe (2010); Garcia-Castro, Ariño and Canela (2010); Lee, Faff and Smith (2009 )).

The literature dealing with specific events, similar to our study, includes nuclear disasters at Three Mile Island in 1979 (Bowen, Castanias and Daley (1983); Hill and Schneeweis (1983 )) and at Chernobyl in 1986 (Kalra, Henderson and Raines )), the destruction of the Challenger Space Shuttle in 1986 (Blose, Bornkamp, Brier, Brown and Frederick (1996); Maloney and Mulherin (2003 )), the Exxon Valdez oil spill in 1989 (Dekel and Scotchmer (1990); Mansur, Cochran and Phillips (1991 )) and the September 11 attack on the World Trade Centre in 2001 (Brown, Cummins, Lewis and Wei (2004); Chari (2004); Doherty, Lamm-Tennant and Starks (2003 )). In each case, the impact on the financial market varies depending on the severity of the incident and the level of information available to the markets, though each event provides insight into the ability of financial markets to deal with essentially unpredictable events.

While the Chernobyl incident took place on 26 April 1986, it was concealed by the Soviet Union Government until 28 April 1986, resulting in a delay in financial market reaction to the event. The reaction to the Three Mile Island nuclear accident was much more rapid, consistent with the more open U.S. political environment. Yet, even with prompt announcement in well-informed financial markets, analysts appear to require time to fully assess the impact of these disasters and so there can be some delay in market reaction, as well as corrections over time. The BP oil spill shares some characteristics with Chernobyl because of the lack of detailed information released in the early stages of the disaster concerning the incident. While there was no evidence of government concealment with respect to the BP oil spill, this rig is located in deep water in the gulf and it proved costly for analysts to get close enough to the failed rig to assess its condition as well as to assess the extent of the spill. Indeed, it was not until 29 
April 2010 that the financial markets began to comprehend the true impact of the explosion (Fodor and Stowe (2010); Friedman and Friedman (2010)).

Further, analysis of the share market reaction to nuclear incidents shows that financial market reaction is fairly selective. The Three Mile Island disaster resulted in considerable losses for the utility, General Public Utilities (GPU), involved in running the failed plant and U.S. based utilities that managed a mixture of nuclear and conventional plant were most affected by the Chernobyl disaster (Bowen, Castanias and Daley (1983); Hill and Schneeweis (1983); Kalra, Henderson and Raines )). Evidence of careful analysis by share market participants is particularly apparent in the share market reaction to the Challenger disaster in 1986, which was both rapid and concentrated, with most attention directed toward one NASA contractor, Morton Thiokol Corporation, that was responsible for the manufacture of the component that failed (Blose, Bornkamp, Brier, Brown and Frederick (1996); Maloney and Mulherin (2003)).

Arguably, the Exxon Valdez spill is closer in nature to the BP spill. It involved a large oil spill from a tanker that grounded in Prince William Sound, Alaska. Again, the share market was quite selective in its reaction to the spill, with the share price of those companies most closely linked with the Trans-Alaska pipeline most affected by the spill (Mansur, Cochran and Phillips (1991 )). One issue that was raised in discussions that followed this event was the economic incentive for oil producers to inadequately equip and train staff to deal with such disasters. The Exxon Valdez spill resulted in increased gasoline prices and it is possible that the industry as a whole may have profited from the spill. Indeed, it can be shown that, under certain circumstances U.S. oil producers, who share spill clean-up costs, will maximize profit by colluding to make inadequate provision for the clean-up of spills (Dekel and Scotchmer (1990 )). The inability of BP plc. and its sub-contractors to successfully deal with the spill and BP plc. agreement that it alone must meet the costs of the clean-up suggest a different, 
perhaps simpler, explanation. Perhaps the disaster is best explained in terms of inadequate training and mechanical failures arising from long term cost cutting by both $\mathrm{BP}$ and its contractors, though it will take some time before an official explanation is provided.

Fodor and Stowe provide an excellent analysis of the impact of the BP spill on the price of BP plc. share price, bonds, options and its credit default spread (Fodor and Stowe (2010)). This is very much a descriptive paper with an emphasis on graphical analysis and descriptive statistics. Perhaps the strongest result to flow from this paper is the graphical evidence of the tight links that exist between these BP plc. securities. We extend upon this work in the following sections with statistical analysis of the impact of the BP spill both on the share price of BP plc. and the share price of other firms involved in crude oil production in the U.S. as these links have implications for the health of the U.S. crude oil industry.

\section{Data}

The initial sample is based on energy firms listed on NYSE, AMEX and NASDAQ over the period 5 March 2009 to 20 September 2010. We identified 231 firms with SIC header code of $13 \mathrm{and} /$ or SIC code of 2911. These SIC codes are widely used in the literature to identify oil and gas firms (Jin and Jorion (2006 )). We use Factiva searches of the Wall Street Journal given the reliability of the information reported in the Wall Street Journal, noted previously in the literature (Mitchell and Mulherin (1994)), to identify those firms retained for analysis and to find news articles focusing on the BP oil spill. Through these searches, we identify 433 articles discussing the BP oil spill and 73 news articles dealing with the moratorium. Three critical dates were identified with respect to the moratorium. These dates were checked against the press release, 'The Deepwater Horizon Response', issued by the U.S. Department of the Interior on its website (http://www.doi.gov/deepwaterhorizon/ ). The first date is 27/05/2010 when an 
order for a six month moratorium on deep water drilling was put in place. The second date is 22/06/2010 when a U.S. District court overruled the order and the last date is 12/07/2010 when the U.S. Department of the Interior issued a new suspension order for deep water drilling in the Gulf. (See table A.1 in Appendix for further details on the event periods subject to analysis.)

The initial list of 231 firms is reduced to 214 firms (including BP plc.), with 17 firms being excluded either because they are classified as delisted (4 firms) or because share price information is not available (13 firms) (See Panel A of Table 1). Nine firms were also excluded because of the announcement of capitalisation changes or merger and acquisition activity during the study period. Panel B of Table 1 provides a breakdown of the sample including BP plc., the four BP sub-contractors, the 26 Moratorium affected firms (moratorium firms) and 183 remaining firms that were identified as not being directly affected by the moratorium (other firms).

\section{Table 1 - Description of portfolio}

Panel A, Sample

\begin{tabular}{l|r}
\hline & Number of Firms \\
\hline $\begin{array}{l}\text { Initial list of oil and gas extraction related firms identified by SIC } \\
\text { code (including BP plc.) }\end{array}$ & 231 \\
\hline Exclude firms announcement of stock splits, dividend, mergers, & 9 \\
acquisitions and divestitures & 4 \\
\hline Exclude firms not available in Thomson Reuter DataStream & 13 \\
Exclude firms delisted during the analysis period & 204 \\
\hline Final sample for analysis (including BP plc.) & \\
\hline
\end{tabular}




\section{Panel B, Classification of Oil and Gas extraction firms included in the study}

Factiva searches are used to identify BP subcontractors, firms affected by moratorium and firms not directly affected by the moratorium (Others) with SIC header code of 13 and/or SIC code of 2911.

\begin{tabular}{|c|c|c|c|}
\hline Portfolio & $\begin{array}{c}\text { \# of } \\
\text { firms }\end{array}$ & SIC Codes & Descriptions of portfolio \\
\hline BP plc. & 1 & Primary code 1311 & \\
\hline BP Subcontractors & 4 & $\begin{array}{l}1311,1389,1381, \\
3492\end{array}$ & $\begin{array}{l}\text { Halliburton is responsible for cementing the well. } \\
\text { Anadarko petroleum was partner of BP in the well. } \\
\text { Cameron International was responsible for blowout } \\
\text { preventer. It has to be noted that Cameron } \\
\text { International is the only firm in the study which has } \\
\text { a non-oil and gas SIC code (3492). Transocean was } \\
\text { the owner of the Deepwater Horizon rig. This is } \\
\text { documented in the Wall street Journal (Some } \\
\text { Energy ETFs Sidestep BP Effect by Ian Salisbury } \\
10 \text { June 2010, The Wall Street Journal.) }\end{array}$ \\
\hline Moratorium firms & 26 & $\begin{array}{l}1011,1311,1321 \\
1381,1382,1389 \\
2911\end{array}$ & $\begin{array}{l}\text { An initial search using Factiva identified all the } \\
\text { major news items regarding the disaster and the } \\
\text { moratorium. This search identified } 14 \text { firms, } \\
\text { excluding BP and its subcontractors, that owned } \\
\text { wells affected by the moratorium. The number of } \\
\text { well owners and their contractors are reported in the } \\
\text { following global insight web site: } \\
\text { http://www.ihsglobalinsight.com/SDA/SDADetail1 } \\
\text { 8866.htm The sample was then extended by adding } \\
\text { other energy firms which did not own any wells but } \\
\text { were active in oil and gas drilling on the } \\
\text { moratorium affected wells (SIC code: } 1381 \text { ). Firms } \\
\text { affected by the moratorium were mainly identified } \\
\text { from news articles. }\end{array}$ \\
\hline Other firms & 183 & $\begin{array}{l}1310,1311,1321 \\
1380,1381,1382 \\
1389,2911\end{array}$ & $\begin{array}{l}\text { There are } 183 \text { oil and gas producing firms that are } \\
\text { listed in the U.S. stock markets but not directly } \\
\text { affected by moratorium. }\end{array}$ \\
\hline Total & 214 & & \\
\hline
\end{tabular}

The share price data are obtained from Thomson Reuters DataStream and share returns are fully adjusted for capitalisation changes and dividends. Analysis is based both on individual firm returns and portfolio returns with both equal-weighting and valueweighting used in portfolio construction. We do not use S\&P 500 sub-industry indices 
for analysis because these indices do not include all of the firms that we identify as being directly affected by the BP oil spill on 20 April 2010. Instead, we create specific purpose portfolios of these firms for analysis. The S\&P 500 composite index provides a proxy for the market portfolio. The U.S. one-month Treasury bill rate is used as a proxy for the risk free rate of return and this is used in calculation of excess returns. The U.S. three-month Treasury bill rate is collected for calculation of the short-term yield curve slope. Finally, to allow separate analysis of the impact of the BP oil spill on crude oil prices and on gas prices, prices were collected for WTI crude oil and for natural gas using closest to maturity New York Mercantile Exchange (NYMEX) futures contract prices. These were obtained from the U.S. Energy Information Administration website (http://www.eia.doe.gov/). Returns are continuously compounding rates of return per day and share returns are expressed as returns in excess of the one-month Treasury bill yield quoted for the day.

Descriptive statistics for returns are reported in Table 3 for the 390 trading day period that is used in analysis. These statistics are calculated for the individual firms, BP plc., Anadarko, Halliburton, Transocean and Cameron International and for the portfolios, equally weighted BP subcontractors (EW BP subcontractors), equally weighted moratorium firms (EW Moratorium), value weighted moratorium firms (VW Moratorium), equally weighted other firms (EW Others) and, value weighted other firms (VW Others). The excess returns are all positive on average, though nonnormally distributed over the combined estimation and event period with average daily excess share returns ranging from a minimum of $4 \%$ per annum, $(0.00017 \times 250 \times 100)$, for Transocean to a maximum of $49 \%$ per annum, $(0.00195 \times 250 \times 100)$, for Cameron International. While returns were generally negative over the period covered by Figure 1 (January 2010 to September 2010) there were also periods of rising prices prior to January 2010, resulting in positive returns on average for the 390 trading day period used in analysis. The standard deviation in share returns varies from a minimum of $28 \%$ 
per annum, $(0.018 \times \sqrt{250} \times 100)$, for the value-weighted portfolio of moratorium firms to a maximum of $51 \%$ per annum, $(0.033 \times \sqrt{250} \times 100)$, for Anadarko. The S\&P 500 composite index returns are considerably less volatile than the individual oil and gas firm returns. The average daily natural gas futures contract return is negative while the return on the daily crude oil futures contract is positive on average. Further, the natural gas return is almost double the volatility of the crude oil futures contract return.

\section{Table 2 Summary Statistics}

Descriptive statistics are reported for each of the dependent and independent variables used in the analysis. $(\mathrm{N}=390)$

\begin{tabular}{|c|c|c|c|c|c|c|}
\hline Variable Name & Mean & Median & $\begin{array}{c}\text { Maximu } \\
m\end{array}$ & $\begin{array}{c}\text { Minimu } \\
\text { m }\end{array}$ & $\begin{array}{l}\text { Std. } \\
\text { Dev. }\end{array}$ & J-Bera \\
\hline \multicolumn{7}{|l|}{ Oil and gas firm/portfolio returns } \\
\hline BP plc. & 0.00036 & 0.00110 & 0.116 & -0.172 & 0.025 & $\begin{array}{c}2381.24 \\
8\end{array}$ \\
\hline Anadarko & 0.00128 & 0.00135 & 0.117 & -0.218 & 0.032 & $\begin{array}{c}1658.00 \\
5\end{array}$ \\
\hline Halliburton & 0.00176 & 0.00059 & 0.113 & -0.160 & 0.028 & 149.661 \\
\hline Transocean & 0.00017 & 0.00106 & 0.100 & -0.126 & 0.029 & 51.863 \\
\hline Cameron International & 0.00195 & 0.00263 & 0.091 & -0.139 & 0.029 & 81.797 \\
\hline EW BP subcontractors & 0.00129 & 0.00113 & 0.080 & -0.158 & 0.026 & 225.109 \\
\hline EW Moratorium firms & 0.00147 & 0.00134 & 0.102 & -0.082 & 0.024 & 16.531 \\
\hline VW Moratorium firms & 0.00057 & 0.00118 & 0.074 & -0.058 & 0.019 & 13.125 \\
\hline EW Other firms & 0.00158 & 0.00116 & 0.089 & -0.08 & 0.022 & 44.472 \\
\hline VW Other firms & 0.00083 & 0.00050 & 0.070 & -0.051 & 0.018 & 16.839 \\
\hline \multicolumn{7}{|l|}{ Control variable returns } \\
\hline S\&P 500 composite index return & 0.00129 & 0.00145 & 0.069 & -0.044 & 0.014 & 106.092 \\
\hline U.S. one month Treasury bill yields & 0.00009 & 0.00008 & 0.007 & -0.008 & 0.002 & 298.051 \\
\hline $\begin{array}{l}\text { Closest to maturity oil futures contract } \\
\text { returns }\end{array}$ & 0.00128 & 0.00095 & 0.105 & -0.093 & 0.024 & 42.171 \\
\hline $\begin{array}{l}\text { Closest to maturity gas futures contract } \\
\text { returns }\end{array}$ & $-\overline{0}-$ & $\begin{array}{c}- \\
0.00545\end{array}$ & 0.269 & -0.098 & 0.041 & 608.850 \\
\hline
\end{tabular}




\section{Method}

Abnormal returns (Ball and Brown (1968); Fama, Fisher, Jensen and Roll (1969)) are used to evaluate the impact of the BP oil spill and the moratorium announcement that followed on selected oil and gas companies listed on U.S. equity markets. The abnormal returns for events of interest are estimated based on an adjusted market model using 390 days starting from 5 March 2009, 285 days prior to the BP oil spill. Since oil and gas firm equity prices are sensitive to changes in oil price, natural gas price and interest rates (Boyer and Filion (2007); El-Sharif, Brown, Burton, Nixon and Russell (2005); Nandha and Faff (2008); Ramos and Veiga ); Sadorsky (2001 )), we add proxies for these factors to the standard market model. ARCH effects have been identified in previous event studies (Cable and Holland (2000); Coutts, Mills and Roberts (1994 )) and, more specifically, Sadorsky ((2001 )) has identified an ARCH effect in oil and gas firm equity returns. We test for ARCH effects using the Lagrange Multiplier test and find evidence of ARCH effects in each of the estimated models. As a result the adjusted market model is estimated within a $\operatorname{GARCH}(1,1)$ framework in the analysis reported below. The mean equation is defined as:

$$
R_{j, t}=\beta_{j}+\beta_{j m} R_{m k t, t}+\beta_{j b} R_{b, t}+\beta_{j o} R_{o, t}+\beta_{j g} R_{g, t}+\sum_{i=1}^{k} \gamma_{j i} D_{i}+\varepsilon_{j, t}
$$

Where $R_{j, t}=$ Daily return on individual firm, or portfolio, $j$ in excess of the onemonth U.S. Treasury bill rate for period $t$, $R_{m k t}=$ Daily return on the $\mathrm{S} \& \mathrm{P} 500$ composite index return in excess of the one-month U.S. Treasury bill rate, $R_{b, t}=$ yield curve slope for the day $t$ calculated as the difference between the threemonth U.S. treasury bill rate and the one-month U.S. treasury bill, $R_{o, t}=$ Daily return calculated for West Texas Intermediate crude oil using the closestto-maturity futures contract prices, 
$R_{g, t}=$ Daily return calculated for natural gas using the closest-to-maturity futures contract prices,

$D_{i}=$ the dummy variable that captures mean abnormal return for event day $i$ $\varepsilon_{j, t}=$ regression residual or error term.

And, the conditional variance takes the form:

$$
\sigma_{j, t}^{2}=\varpi_{j}+\varphi_{j} \varepsilon_{j, t-1}^{2}+\eta_{j} \sigma_{j, t-1}^{2}
$$

Where $\sigma_{j, t}^{2}=$ conditional variance for day $t$,

$\varepsilon_{j, t}^{2}=$ mean equation squared residual for day $t$.

\section{Results}

Initial analysis focuses on abnormal returns for BP plc. and the four key subcontractors, Anadarko, Halliburton, Transocean and Cameron International. To assess the impact of the BP oil spill on other oil and gas firms listed on the U.S. share markets we construct value-weighted and equally-weighted portfolios for two groups of oil and gas producers: those directly involved in oil and gas production in the gulf (moratorium firms) and those not directly involved in oil and gas production in the gulf (other firms). There are also two groups of announcements that we focus on in the following analysis. The first group of announcements includes the BP explosion, the initial moratorium, the subsequent overruling of this moratorium and the imposition of the second Moratorium. The second group consists of the BP explosion and the announcements concerning the two attempts to fix the spill, Top-kill and Static-kill (See Appendix).

The adjusted market model used in analysis includes short-term yield curve slope effects and the impact of oil prices and gas prices as well as the market risk premium. In all cases the estimated market risk premium coefficient is statistically significant and positive. The coefficient value is generally around 0.75 for BP plc. with values fairly close to one for the individual subcontractors and for the oil and gas firm 
portfolios. The oil price coefficient is positive and statistically significant in all regressions and, with the exception of BP plc., the gas price coefficient is also positive and statistically significant. The yield curve slope is not statistically significant in any of the analyses. There is evidence of time changing variance in the residuals of each of the adjusted market models and so the adjusted model is couched within a GARCH (1, 1) framework as discussed above. In all cases, the sum of the estimated GARCH coefficient $\left(\eta_{j}\right)$ and the ARCH coefficient $\left(\varphi_{j}\right)$ is less than one. Further, the GARCH coefficient is always statistically significant, though ARCH coefficients for value weighted portfolios for both the moratorium firms or for the other firms are not statistically significant.

\subsection{BP oil Spill and subsequent moratorium related announcements}

The BP oil spill has a considerable impact on the share price of BP plc. and its subcontractors. This section focuses on the BP oil spill announcement and the moratorium related announcements that follow. The results from analysis are reported in Table 3 with specific attention directed at BP plc. and its subcontractors, Anadarko, Halliburton, Transocean and Cameron International. Table 3 also includes a set of results for an equally-weighted portfolio of the four subcontractors.

\section{Table 3 Abnormal returns of BP and BP subcontractors}

This table reports the result of regression analysis where the dependent variable is the individual firm or portfolio daily returns for BP plc. and BP subcontractors in excess of the one-month Treasury bill rate. The independent variables include the daily return on the equity market returns (S\&P500 composite index) in excess of the one-month Treasury bill rate (Market), the yield curve slope (three-month Treasury bill rate less the one-month Treasury bill rate), the closest-to-maturity oil future contract return (Oil futures) and the closest-to-maturity gas future contract return (Gas futures). The remaining independent variables consist of announcement date dummy variables that take a value of one on the chosen event day/s and zero otherwise. BP explosion (22 April 2010) was the day of the official BP announcement regarding the well explosion. Pre-moratorium (25 May 2010 to 26 May 2010) includes the two trading days before the introduction of the first moratorium. Moratorium (27 May 2010 to 1 June 
$2010)$ is the day the first moratorium was announced and the following two trading days. President Obama's statement and BP response (9 June 2010 to 10 June 2010) include the day of President Obama's statement and BP's response concerning responsibility for the incident on the following day. Preoverruling (18 June 2010 to 21 June 2010) includes the two trading days before the moratorium overruling was announced. Overruling (22 June 2010 to 24 June 2010) includes the day of the overruling of the moratorium and the following two trading days. Pre-moratorium 2 (8 July 2010 to 9 July 2010) includes the two trading days before the introduction of the second moratorium. Moratorium 2 (12 July 2010 to 14 July 2010) includes the day of moratorium and the two following trading days. Standard of error is reported in parenthesis. * refers to $5 \%$ level of significant.

\begin{tabular}{|c|c|c|c|c|c|c|}
\hline Variable Name & $\begin{array}{c}\mathrm{BP} \\
(\mathrm{n}=1)\end{array}$ & $\begin{array}{c}\text { Anadarko } \\
(\mathrm{n}=1)\end{array}$ & $\begin{array}{c}\text { Halliburto } \\
n \\
(n=1)\end{array}$ & $\begin{array}{c}\text { Transocea } \\
n \\
(n=1)\end{array}$ & $\begin{array}{c}\text { Cameron } \\
\text { Internationa } \\
1 \\
(n=1)\end{array}$ & $\begin{array}{c}\text { BP Sub- } \\
\text { Contractor } \\
\text { s } \\
(n=4)\end{array}$ \\
\hline Intercept & $\begin{array}{c}0.0000 \\
(0.0007)\end{array}$ & $\begin{array}{c}0.0002 \\
(0.0008)\end{array}$ & $\begin{array}{c}0.0006 \\
(0.0009)\end{array}$ & $\begin{array}{l}-0.0008 \\
(0.0009)\end{array}$ & $\begin{array}{c}0.0005 \\
(0.0008)\end{array}$ & $\begin{array}{r}0.0000 \\
(0.0006)\end{array}$ \\
\hline Market & $\begin{array}{l}0.7542 * \\
(0.0595)\end{array}$ & $\begin{array}{l}1.1563 * \\
(0.0857)\end{array}$ & $\begin{array}{l}1.1862 * \\
(0.0807)\end{array}$ & $\begin{array}{l}1.0380 * \\
(0.0844)\end{array}$ & $\begin{array}{l}1.3155^{*} \\
(0.0751)\end{array}$ & $\begin{array}{l}1.1892 * \\
(0.0615)\end{array}$ \\
\hline Yield curve slope & $\begin{array}{c}0.0321 \\
(0.4883)\end{array}$ & $\begin{array}{c}0.1584 \\
(0.6380)\end{array}$ & $\begin{array}{c}0.2428 \\
(0.5966)\end{array}$ & $\begin{array}{c}0.2537 \\
(0.5321)\end{array}$ & $\begin{array}{l}-0.5826 \\
(0.4485)\end{array}$ & $\begin{array}{l}-0.2564 \\
(0.4122)\end{array}$ \\
\hline Oil futures & $\begin{array}{l}0.1539 * \\
(0.0322)\end{array}$ & $\begin{array}{l}0.2087 * \\
(0.0434)\end{array}$ & $\begin{array}{l}0.2513 * \\
(0.0471)\end{array}$ & $\begin{array}{l}0.2481 * \\
(0.0431)\end{array}$ & $\begin{array}{l}0.3394 * \\
(0.0411)\end{array}$ & $\begin{array}{l}0.2528 * \\
(0.0303)\end{array}$ \\
\hline Gas futures & $\begin{array}{c}0.0053 \\
(0.0145)\end{array}$ & $\begin{array}{l}0.0729 * \\
(0.0175)\end{array}$ & $\begin{array}{l}0.0624 * \\
(0.0206)\end{array}$ & $\begin{array}{l}0.0750 * \\
(0.0205)\end{array}$ & $\begin{array}{l}0.0482 * \\
(0.0165)\end{array}$ & $\begin{array}{l}0.0633 * \\
(0.0142)\end{array}$ \\
\hline $\begin{array}{l}\text { BP Explosion } \\
(0 \text { to }+5)\end{array}$ & $\begin{array}{l}-0.0262 * \\
(0.0031)\end{array}$ & $\begin{array}{l}-0.0180^{*} \\
(0.0026)\end{array}$ & $\begin{array}{l}-0.0161 * \\
(0.0030)\end{array}$ & $\begin{array}{l}-0.0338 * \\
(0.0034)\end{array}$ & $\begin{array}{l}-0.0401 * \\
(0.0028)\end{array}$ & $\begin{array}{l}-0.0288^{*} \\
(0.0020)\end{array}$ \\
\hline $\begin{array}{l}\text { Pre Moratorium } \\
(+25 \text { to }+26)\end{array}$ & $\begin{array}{l}0.0526 * \\
(0.0134)\end{array}$ & $\begin{array}{l}-0.0383^{*} \\
(0.0081)\end{array}$ & $\begin{array}{l}-0.0084 \\
(0.0166)\end{array}$ & $\begin{array}{c}0.0414 \\
(0.0404)\end{array}$ & $\begin{array}{c}0.0226 \\
(4.6750)\end{array}$ & $\begin{array}{l}0.0303 * \\
(0.0153)\end{array}$ \\
\hline $\begin{array}{l}\text { First Moratorium } \\
(+27 \text { to }+29)\end{array}$ & $\begin{array}{l}-0.0539 * \\
(0.0116)\end{array}$ & $\begin{array}{l}-0.0863^{*} \\
(0.0068)\end{array}$ & $\begin{array}{l}-0.0663^{*} \\
(0.0042)\end{array}$ & $\begin{array}{l}-0.0567 * \\
(0.0163)\end{array}$ & $\begin{array}{l}-0.0479 * \\
(0.0051)\end{array}$ & $\begin{array}{r}-0.0657 * \\
(0.0044)\end{array}$ \\
\hline $\begin{array}{l}\text { 9-10 June } \\
\text { Statements } \\
(+35 \text { to }+36)\end{array}$ & $\begin{array}{l}-0.0604 * \\
(0.0132)\end{array}$ & $\begin{array}{r}-0.0758 * \\
(0.0112)\end{array}$ & $\begin{array}{c}0.0062 \\
(0.0216)\end{array}$ & $\begin{array}{l}-0.0390 \\
(0.0243)\end{array}$ & $\begin{array}{c}0.0100 \\
(0.0294)\end{array}$ & $\begin{array}{r}-0.0216 * \\
(0.0085)\end{array}$ \\
\hline $\begin{array}{l}\text { Pre Overruling } \\
(+42 \text { to }+43)\end{array}$ & $\begin{array}{l}-0.0205 \\
(0.0352)\end{array}$ & $\begin{array}{c}0.0234 \\
(1.5621)\end{array}$ & $\begin{array}{c}0.0128 \\
(0.0589)\end{array}$ & $\begin{array}{l}0.0451 * \\
(0.0230)\end{array}$ & $\begin{array}{l}-0.0039 \\
(0.0139)\end{array}$ & $\begin{array}{c}0.0196 \\
(0.0277)\end{array}$ \\
\hline $\begin{array}{l}\text { Overruling } \\
(+44 \text { to }+46)\end{array}$ & $\begin{array}{l}0.0207^{*} \\
(0.0090)\end{array}$ & $\begin{array}{l}-0.0315 \\
(0.1234)\end{array}$ & $\begin{array}{l}-0.0076 \\
(0.0432)\end{array}$ & $\begin{array}{l}-0.0117 \\
(0.0451)\end{array}$ & $\begin{array}{l}-0.0066 \\
(0.0197)\end{array}$ & $\begin{array}{l}-0.0141 \\
(0.0690)\end{array}$ \\
\hline $\begin{array}{l}\text { Pre Moratorium } 2 \\
(+56 \text { to }+57)\end{array}$ & $\begin{array}{c}0.0175 \\
(0.0676)\end{array}$ & $\begin{array}{c}0.0450 \\
(0.0360)\end{array}$ & $\begin{array}{c}0.0123 \\
(0.4792)\end{array}$ & $\begin{array}{c}0.0160 \\
(0.0896)\end{array}$ & $\begin{array}{c}0.0076 \\
(0.0575)\end{array}$ & $\begin{array}{c}0.0200 \\
(0.1416)\end{array}$ \\
\hline
\end{tabular}




\begin{tabular}{l|cccccc}
\hline $\begin{array}{l}\text { Moratorium 2 } \\
(+58 \text { to }+60)\end{array}$ & $0.0349^{*}$ & 0.0126 & -0.0128 & -0.0036 & -0.0111 & -0.0049 \\
\hline $\mathrm{C}$ & $(0.0099)$ & $(0.0129)$ & $(0.0164)$ & $(0.0100)$ & $(0.0127)$ & $(0.0073)$ \\
\hline \multirow{2}{*}{$\mathrm{RESID}(-1)^{\wedge} 2$} & $0.0000^{*}$ & $0.0000^{*}$ & 0.0000 & $0.0000^{*}$ & $0.0000^{*}$ & $0.0000^{*}$ \\
& $(0.0000)$ & $(0.0000)$ & $(0.0000)$ & $(0.0000)$ & $(0.0000)$ & $(0.0000)$ \\
& $0.3445^{*}$ & $0.1735^{*}$ & $0.0678^{*}$ & $0.0999^{*}$ & $0.1322^{*}$ & $0.0970^{*}$ \\
GARCH$(-1)$ & $(0.0645)$ & $(0.0360)$ & $(0.0227)$ & $(0.0240)$ & $(0.0283)$ & $(0.0258)$ \\
& $0.5534^{*}$ & $0.7870^{*}$ & $0.8952^{*}$ & $0.8834^{*}$ & $0.8261^{*}$ & $0.8749^{*}$ \\
\hline Adj-Rsquare & $(0.0570)$ & $(0.0394)$ & $(0.0338)$ & $(0.0255)$ & $(0.0360)$ & $(0.0322)$ \\
S.E of regression & 0.2746 & 0.4989 & 0.5748 & 0.4607 & 0.6145 & 0.6820 \\
\hline
\end{tabular}

The Deepwater Horizon explosion was first announced in the Wall Street Journal on the 22 April 2010 and this resulted in a six-day $(0$ to +5$)$ abnormal return of $-2.62 \%$ for BP plc. While we focus on share price reactions to the explosion and the events that followed, BP bonds, options and credit default swaps reflect similar changes over this period (Fodor and Stowe (2010)). The equally weighted portfolio of the four major BP subcontractors also generated an abnormal return of $-2.88 \%$, spread rather unevenly across the contractors with the abnormal returns for Anadarko of $-1.80 \%$, Halliburton $-1.61 \%$, Transocean $-3.38 \%$ and Cameron International $-4.01 \%$. This dispersion may well be related to the part that each of the subcontractors played in the disaster. For example, it is Cameron International that supplied the 'blowout preventer' to Transocean who owned the Deepwater Horizon rig. It is the blowout preventer that is widely believed to have caused to the Deepwater Horizon explosion. Thus, it is not surprising that the initial share market reaction was greatest for both Cameron International and Transocean on the 22 April 2010. In effect, this reflects the share market view of the role of these two companies in the explosion and the costs that they will incur as a result. The share price reaction evident for Anadarko and Halliburton are more in line with the BP share price reaction on the day. These smaller adjustments 
appear consistent with the later refusal of both parties to contribute to the costs of the clean-up following their argument that the criminal actions of BP plc. limited any claim that might be lodged against them. Nevertheless, the one-day adjustments are severe enough to suggest that these two firms must also share some responsibility for the events that unfolded with the Deepwater Horizon explosion on 20 April 2010.

The Department of the Interior introduced a moratorium on further development in the Gulf and this was announced on the 27 May 2010. It has been argued that President Obama faced pressure to react to the disaster from environmental groups, independent lawmakers (Senators and Representatives) (Eilperin (2010)) and his own electorate. The BP oil spill occurred at an inopportune time for President Obama and the democrat-controlled Congress. A few weeks before the BP oil spill, the President had broken an electoral promise by allowing the extension of oil and gas exploration in Outer Continental Shelf in the Atlantic, the Gulf of Mexico and Alaska. While few saw President Obama's controversial decision as a political move (Leahy and Eilperin (2010)), many perceived it as betrayal in the wake of the spill. Some suggested it marked a clear failure to understand the potential risks associated with deep-water drilling. With the November midterm congressional elections only a few months away, Obama moved to reduce the political impact from the oil spill with the introduction of the Moratorium. The announcement of the moratorium had a considerable impact on both BP plc. and its subcontractors (Table 3). Indeed, BP plc. suffered a return of $-5.39 \%$ and the average abnormal return for the subcontractors was $-6.57 \%$. These firms had considerable investment in the gulf and their future was closely linked with further development of oil and gas reserves in this area. Anadarko's share price was most affected on the announcement of the moratorium (-8.63\%) and Cameron International was least affected (-4.79\%).

The moratorium was not without its problems and on the 22 June 2010 it was announced that a Federal judge had overruled it. While there was a positive abnormal 
share price return on the announcement for BP plc. (2.07\%) there was no statistically significant effect on the share price of its subcontractors. Similarly, when the second version of the moratorium was announced there was no statistically significant share price response observed for any of the four subcontractors, though BP plc. saw a further $3.49 \%$ increase in value.

There are two important political statements that were made during this period that had a considerable impact on financial markets and this brought to the forefront the importance of politics in this disaster. On the 9 June 2010 President Obama made a statement about the implications of the oil spill for BP plc. and on the 10 June 2010 BP plc. responded to this statement. The result of this interaction was a considerable fall in the share price of both BP plc. $(-6.04 \%)$ and Anadarko (-7.58\%) though the adjustment for the other subcontractors was not statistically significant. Perhaps this is not surprising given Anadarko's 25 per cent working interest in the BP Macondo Prospect. The interests of both BP plc. and Anadarko are closely linked to the BP oil spill and so it is expected that if Government sanctions are introduced then these two firms will bear the brunt of these sanctions. The three remaining subcontractors had already suffered considerable loss in share value. Further, they were not as directly linked in terms of ownership and control of the BP Macondo Prospect.

While the BP oil spill had clear implications for BP plc. and its subcontractors the moratorium raised a more important question for the oil and gas industry. Few argued against BP plc. bearing the costs of rectifying the spill but many were surprised by the introduction of the moratorium because this has serious implications for the future of U.S. oil and gas production in the gulf. To gain some indication of the impact of this regulatory response for the oil and gas industry we analysed the abnormal returns earned by equally weighted and value weighted portfolios of two groups of oil and gas producers. The first consisted of those firms directly associated with oil and gas production in the gulf (moratorium firms). The second consisted of those with no direct 
links with the Gulf (other firms). The results of analysis of these portfolios highlight the impact of the moratorium on oil and gas producers (Table 4). On announcement of the moratorium by the Department of the Interior the equally weighted portfolio of moratorium firms earned an abnormal return of $-2.12 \%$ while the value weighted portfolio earned an abnormal return of $-0.65 \%$. Both of these estimated abnormal returns are statistically significantly different from zero though the variation in the performance of these two portfolios suggests that the smaller firms in this group suffered more from the moratorium than the larger firms. Finally, it is important to note that there is no other statistically significant abnormal return reported for the event periods at the 5\% level of significance in Table 4 . Thus, the share prices of those firms not directly involved in oil and gas production in the gulf were not statistically significantly affected by the moratorium announcement.

\section{Table 4 Abnormal Returns to Moratorium firm portfolios and other firm portfolios}

This table reports the result of regression analysis where the dependent variable is the portfolio daily returns for moratorium firms and for other firms in excess of the one-month Treasury bill rate. Moratorium firms are those firms involved in crude oil and gas extraction in the Gulf. The independent variables include the daily return on the equity market returns (S\&P500 composite index) in excess of the one-month Treasury bill rate (Market), the yield curve slope (three-month Treasury bill rate less the onemonth Treasury bill rate), the closest-to-maturity oil future contract return (Oil futures) and the closest-tomaturity gas future contract return (Gas futures). The remaining independent variables consist of announcement date dummy variables that take a value of one on the chosen event day/s and zero otherwise. BP explosion (22 April 2010) was the day of the official BP announcement regarding the well explosion. Pre-moratorium (25 May 2010 to 26 May 2010) includes the two trading days before the introduction of the first moratorium. Moratorium (27 May 2010 to 1 June 2010) is the day the first moratorium was announced and the following two trading days. President Obama's statement and BP response (9 June 2010 to 10 June 2010) include the day of President Obama's statement and BP's response concerning responsibility for the incident on the follow day. Pre-overruling (18 June 2010 to 21 June 2010) includes the two trading days before the moratorium overruling was announced. Overruling (22 June 2010 to 24 June 2010) includes the day of the overruling of the moratorium and the following two trading days. Pre-moratorium 2 (8 July 2010 to 9 July 2010) includes the two trading days before the introduction of the second moratorium. Moratorium 2 (12 July 2010 to 14 July 2010) includes the day of moratorium and the two following trading days. Standard of error is reported in parenthesis. * refers to $5 \%$ level of significant. 


\begin{tabular}{|c|c|c|c|c|}
\hline Variable Name & $\begin{array}{l}\text { Moratorium } \\
\text { Firms }(E W) \\
(n=26)\end{array}$ & $\begin{array}{l}\text { Moratorium } \\
\text { Firms }(V W) \\
(n=26)\end{array}$ & $\begin{array}{l}\text { Other Firms } \\
(E W) \\
(n=183)\end{array}$ & $\begin{array}{l}\text { Other Firms }(V W) \\
(n=183)\end{array}$ \\
\hline Intercept & $\begin{array}{l}-0.0003 \\
(0.0004)\end{array}$ & $\begin{array}{l}-0.0008^{*} \\
(0.0003)\end{array}$ & $\begin{array}{c}0.0000 \\
(0.0005)\end{array}$ & $\begin{array}{l}-0.0005^{*} \\
(0.0003)\end{array}$ \\
\hline Market & $\begin{array}{l}1.2830 * \\
(0.0369)\end{array}$ & $\begin{array}{l}1.1100 * \\
(0.0292)\end{array}$ & $\begin{array}{l}1.0742 * \\
(0.0418)\end{array}$ & $\begin{array}{l}0.9781 * \\
(0.0251)\end{array}$ \\
\hline Yield curve slope & $\begin{array}{l}-0.1692 \\
(0.2593)\end{array}$ & $\begin{array}{l}-0.2161 \\
(0.2105)\end{array}$ & $\begin{array}{c}0.1249 \\
(0.2781)\end{array}$ & $\begin{array}{l}-0.1004 \\
(0.1938)\end{array}$ \\
\hline Oil futures & $\begin{array}{l}0.2635^{*} \\
(0.0215)\end{array}$ & $\begin{array}{l}0.1800^{*} \\
(0.0146)\end{array}$ & $\begin{array}{l}0.2710^{*} \\
(0.0225)\end{array}$ & $\begin{array}{l}0.1908^{*} \\
(0.0128)\end{array}$ \\
\hline Gas futures & $\begin{array}{l}0.0721^{*} \\
(0.0095)\end{array}$ & $\begin{array}{l}0.0255^{*} \\
(0.0069)\end{array}$ & $\begin{array}{l}0.0671 * \\
(0.0089)\end{array}$ & $\begin{array}{c}0.0312 * \\
(0.0063)\end{array}$ \\
\hline $\begin{array}{l}\text { BP Explosion } \\
(0 \text { to }+5)\end{array}$ & $\begin{array}{l}-0.0031 \\
(0.0030)\end{array}$ & $\begin{array}{l}-0.0005 \\
(0.0016)\end{array}$ & $\begin{array}{l}0.0020 \\
(0.0037)\end{array}$ & $\begin{array}{l}-0.0004 \\
(0.0020)\end{array}$ \\
\hline $\begin{array}{l}\text { Pre Moratorium } \\
(+25 \text { to }+26)\end{array}$ & $\begin{array}{c}0.0055 \\
(0.0070)\end{array}$ & $\begin{array}{l}-0.0012 \\
(0.0028)\end{array}$ & $\begin{array}{c}0.0045 \\
(0.0143)\end{array}$ & $\begin{array}{l}-0.0009 \\
(0.0057)\end{array}$ \\
\hline $\begin{array}{l}\text { First Moratorium } \\
(+27 \text { to }+29)\end{array}$ & $\begin{array}{l}-0.0212 * \\
(0.0032)\end{array}$ & $\begin{array}{l}-0.0065^{*} \\
(0.0032)\end{array}$ & $\begin{array}{l}-0.0048 \\
(0.0029)\end{array}$ & $\begin{array}{c}0.0040 \\
(0.0023)\end{array}$ \\
\hline $\begin{array}{l}\text { 9-10 June Statements } \\
(+35 \text { to }+36)\end{array}$ & $\begin{array}{c}0.0053 \\
(0.0053)\end{array}$ & $\begin{array}{c}0.0046 \\
(0.0028)\end{array}$ & $\begin{array}{c}0.0008 \\
(0.0379)\end{array}$ & $\begin{array}{c}0.0028 \\
(0.0032)\end{array}$ \\
\hline $\begin{array}{l}\text { Pre Overruling } \\
(+42 \text { to }+43)\end{array}$ & $\begin{array}{c}0.0071 \\
(0.0765)\end{array}$ & $\begin{array}{c}0.0037 \\
(0.0065)\end{array}$ & $\begin{array}{l}-0.0029 \\
(0.0122)\end{array}$ & $\begin{array}{c}0.0030 \\
(0.0807)\end{array}$ \\
\hline $\begin{array}{l}\text { Overruling } \\
(+44 \text { to }+46)\end{array}$ & $\begin{array}{l}-0.0042 \\
(0.0176)\end{array}$ & $\begin{array}{l}-0.0022 \\
(0.0067)\end{array}$ & $\begin{array}{l}-0.0022 \\
(0.0385)\end{array}$ & $\begin{array}{l}-0.0037 \\
(0.0050)\end{array}$ \\
\hline $\begin{array}{l}\text { Pre Moratorium } 2 \\
(+56 \text { to }+57)\end{array}$ & $\begin{array}{l}-0.0038 \\
(0.0305)\end{array}$ & $\begin{array}{l}-0.0030 \\
(0.0043)\end{array}$ & $\begin{array}{l}-0.0032 \\
(0.0061)\end{array}$ & $\begin{array}{l}-0.0034 \\
(0.0064)\end{array}$ \\
\hline $\begin{array}{l}\text { Moratorium } 2 \\
(+58 \text { to }+60)\end{array}$ & $\begin{array}{l}-0.0074 \\
(0.0044)\end{array}$ & $\begin{array}{l}-0.0016 \\
(0.0058)\end{array}$ & $\begin{array}{l}-0.0047 \\
(0.0112)\end{array}$ & $\begin{array}{l}-0.0040 \\
(0.0047)\end{array}$ \\
\hline $\mathrm{C}$ & $\begin{array}{c}0.0000 \\
(0.0000)\end{array}$ & $\begin{array}{c}0.0000 \\
(0.0000)\end{array}$ & $\begin{array}{l}0.0000^{*} \\
(0.0000)\end{array}$ & $\begin{array}{c}0.0000 \\
(0.0000)\end{array}$ \\
\hline $\operatorname{RESID}(-1)^{\wedge} 2$ & $\begin{array}{l}-0.0189 \\
(0.0101)\end{array}$ & $\begin{array}{c}0.0151 \\
(0.0140)\end{array}$ & $\begin{array}{l}0.0861 * \\
(0.0313)\end{array}$ & $\begin{array}{c}0.0236 \\
(0.0160)\end{array}$ \\
\hline GARCH(-1) & $1.0184 *$ & $0.9688 *$ & $0.8257 *$ & $0.9628 *$ \\
\hline
\end{tabular}




\begin{tabular}{l|cccc}
\hline & $(0.0178)$ & $(0.0183)$ & $(0.0648)$ & $(0.0203)$ \\
\hline Adj-Rsquare & 0.8516 & 0.8781 & 0.8525 & 0.8835 \\
S.E of regression & 0.0094 & 0.0067 & 0.0086 & 0.0060 \\
\hline
\end{tabular}

There is some contention in the literature about whether structural changes in event study analysis like those reported above could bias the results. As a robustness test we re-estimated the analysis reported in Tables 3 and 4 including multiplicative dummy variables to capture the possibility of a structural change in adjusted market model coefficients following the BP oil announcement on 22 April 2010. While not reported separately, there was little evidence of a statistically significant change in the adjusted market model coefficients. The BP oil spill and, more importantly, the event period abnormal returns were essentially unchanged.

\subsection{Announcements of the BP oil spill and attempt to correct it}

In this section we discuss the impact of the attempts by BP plc. to stem the flow of crude oil from the ocean bed and so we repeat the analysis using a set of three event periods, the BP explosion announcement plus 5 days, the Top-kill announcement period and the Static-kill announcement period (see Appendix for definitions). The results from this analysis are reported in Table 5 for BP plc. and its subcontractors with statistically significant negative share market reactions for both the BP explosion announcement period and the Top-kill announcement period. The share market reaction to Static-kill is generally positive though it is only statistically significant for Transocean. While there was considerable information being assimilated by the share market over the period it would seem that the market was not particularly impressed 
with the Top-kill solution, with considerable negative share price reaction earned by

both BP plc. and Anadarko in particular.

Table 5 Abnormal returns of BP and BP subcontractors, attempts to stem the leak

This table reports the result of regression analysis where the dependent variable is the individual firm or portfolio daily returns for BP plc. and BP subcontractors in excess of the one-month Treasury bill rate. The independent variables include the daily return on the equity market returns (S\&P500 composite index) in excess of the one-month Treasury bill rate (Market), the yield curve slope (three-month Treasury bill rate less the one-month Treasury bill rate), the closest-to-maturity oil future contract return (Oil futures) and the closest-to-maturity gas future contract return (Gas futures). The remaining independent variables consist of announcement date dummy variables that take a value of one on the chosen event days and zero otherwise. BP explosion $(0$ to +5$)(22$ April 2010 to 29 April 2010) includes the BP explosion plus the following 5 trading days. Top-kill (28 May 2010 to 1 June 2010) includes the trading day before the first major attempt of BP at plugging the oil leak, the day of the attempt (29 May 2010) and the trading day after. Static-kill (3 August 2010 to 5 August 2010) includes the trading day before the successful second attempt by BP to plug the leak, the day of the attempt (4 August 2010) and the following trading day. Standard of error is reported in parenthesis. * refers to $5 \%$ level of significant.

\begin{tabular}{l|ccccccc}
\hline Variable Name & $\begin{array}{l}\text { BP } \\
(n=1)\end{array}$ & $\begin{array}{l}\text { Anadarko } \\
(n=1)\end{array}$ & $\begin{array}{l}\text { Haliburton } \\
(n=1)\end{array}$ & $\begin{array}{l}\text { Transocean } \\
(n=1)\end{array}$ & $\begin{array}{l}\text { Cameron } \\
\text { International } \\
(n=1)\end{array}$ & $\begin{array}{l}\text { EW BP Sub } \\
\text { contractors } \\
(n=4)\end{array}$ \\
\hline Intercept & 0.0001 & 0.0001 & 0.0004 & -0.0008 & 0.0004 & -0.0001 \\
& $(0.0008)$ & $(0.0008)$ & $(0.0009)$ & $(0.0009)$ & $(0.0008)$ & $(0.0006)$ \\
Market & $0.7582^{*}$ & $1.1764^{*}$ & $1.1836^{*}$ & $1.0388^{*}$ & $1.3296^{*}$ & $1.1993^{*}$ \\
Yield curve slope & $(0.0644)$ & $(0.0865)$ & $(0.0818)$ & $(0.0849)$ & $(0.0796)$ & $(0.0601)$ \\
& -0.0238 & 0.1406 & 0.1130 & 0.2914 & -0.6165 & -0.2741 \\
Oil futures & $(0.5026)$ & $(0.6739)$ & $(0.5964)$ & $(0.5311)$ & $(0.4626)$ & $(0.4109)$ \\
& $0.1443^{*}$ & $0.2079^{*}$ & $0.2623^{*}$ & $0.2458^{*}$ & $0.3335^{*}$ & $0.2525^{*}$ \\
Gas futures & $(0.0337)$ & $(0.0453)$ & $(0.0471)$ & $(0.0431)$ & $(0.0427)$ & $(0.0301)$ \\
& 0.0062 & $0.0717^{*}$ & $0.0609^{*}$ & $0.0755^{*}$ & $0.0460^{*}$ & $0.0617^{*}$ \\
\hline BP Explosion & $(0.0151)$ & $(0.0178)$ & $(0.0208)$ & $(0.0205)$ & $(0.0164)$ & $(0.0144)$ \\
$(0$ to +5) & $-0.0283^{*}$ & $-0.0185^{*}$ & $-0.0169^{*}$ & $-0.0338^{*}$ & $-0.0404^{*}$ & $-0.0289^{*}$ \\
TOPKILL & $(0.0027)$ & $(0.0025)$ & $(0.0032)$ & $(0.0034)$ & $(0.0028)$ & $(0.0020)$ \\
\hline
\end{tabular}




\begin{tabular}{l|cccccc}
\hline$(+28$ TO +30 & $(0.0059)$ & $(0.0039)$ & $(0.0065)$ & $(0.0272)$ & $(0.0055)$ & $(0.0038)$ \\
STATICKILL & 0.0065 & 0.0223 & 0.0044 & $0.0461^{*}$ & -0.0088 & $0.0163^{*}$ \\
$(+74$ TO +76) & $(0.0059)$ & $(0.0319)$ & $(0.0102)$ & $(0.0206)$ & $(0.0051)$ & $(0.0077)$ \\
\hline $\mathrm{C}$ & $0.0000^{*}$ & $0.0000^{*}$ & $0.0000^{*}$ & $0.0000^{*}$ & $0.0000^{*}$ & $0.0000^{*}$ \\
& $(0.0000)$ & $(0.0000)$ & $(0.0000)$ & $(0.0000)$ & $(0.0000)$ & $(0.0000)$ \\
RESID $(-1)^{\wedge} 2$ & $0.2250^{*}$ & $0.1575^{*}$ & $0.1088^{*}$ & $0.0980^{*}$ & $0.1267^{*}$ & $0.1098^{*}$ \\
& $(0.0381)$ & $(0.0270)$ & $(0.0316)$ & $(0.0222)$ & $(0.0270)$ & $(0.0276)$ \\
GARCH(-1) & $0.7076^{*}$ & $0.8220^{*}$ & $0.8466^{*}$ & $0.8853^{*}$ & $0.8440^{*}$ & $0.8616^{*}$ \\
& $(0.0413)$ & $(0.0283)$ & $(0.0465)$ & $(0.0229)$ & $(0.0291)$ & $(0.0357)$ \\
\hline Adj-Rsquare & 0.3066 & 0.4604 & 0.5423 & 0.4663 & 0.6041 & 0.6593 \\
S.E of regression & 0.0207 & 0.0233 & 0.0188 & 0.0213 & 0.0183 & 0.0151 \\
\hline
\end{tabular}

Analysis of the remainder of the oil and gas industry, split into the moratorium firms and other firms, shows little share price reaction to these events (Table 6). The only exception is for the equally weighted moratorium firm portfolio. Comparison between the value weighted and equally weighted moratorium firm portfolios suggest that while the larger oil and gas producer share prices were little affected by attempts at plugging the leak in the ocean floor the smaller firm share prices were more sensitive to these attempts with a negative reaction to Top-kill and a positive reaction to Static-kill.

\section{Conclusion}

We provide evidence of a focused share market reaction to the BP oil spill on the 22 April 2010, particularly with respect to BP plc. and its subcontractors. The differential share market reaction to Cameron International and to Transocean further highlights the 
ability of the share market to identify those firms most likely to be responsible for the actual disaster (Leahy and Eilperin (2010)). The failure of the blowout preventer, supplied by Cameron International and installed by Transocean, has been cited as one of the key events that lead to the explosion at the rig and these firms were most heavily penalised by the market on announcement of the BP oil spill. The use of a blowout preventer was also specifically mentioned in the second attempt at setting up a moratorium on deep-water wells in the gulf.

This disaster also drew attention to the importance of the environmental impact of off-shore oil and gas exploration to U.S. oil and gas development policy. The need for oil and gas exploration and development and the politically sensitive environmental issues associated with it were highlighted with the BP oil spill. It would seem that the moratorium was politically motivated and its early demise tends to support this contention. Nevertheless, the moratorium had considerable economic implications for the oil and gas industry, particularly those operating in the gulf. As might be expected the share market reacted rapidly to the moratorium and this adjustment highlighted the problems associated with such a blunt policy instrument.

\section{Acknowledgements}

We thank the anonymous referee and the editors for their comments and suggestions.

\section{Funding}

We thank the ARC for its financial support (Discovery grant DP0770537). 


\section{Table 6 Abnormal Returns to Moratorium firm portfolios and other firm portfolios, attempts to stem the leak}

This table reports the result of regression analysis where the dependent variable is the portfolio daily returns for moratorium affected firms and for other firms in excess of the one-month Treasury bill rate. Moratorium firms are those firms involved in crude oil and gas extraction in the Gulf. The independent variables include the daily return on the equity market returns (S\&P500 composite index) in excess of the one-month Treasury bill rate (Market), the yield curve slope (three-month Treasury bill rate less the onemonth Treasury bill rate), the closest-to-maturity oil future contract return (Oil futures) and the closest-tomaturity gas future contract return (Gas futures). The remaining independent variables consist of announcement date dummy variables that take a value of one on the chosen event day/s and zero otherwise. BP explosion (0 to +5) (22 April 2010 to 29 April 2010) includes the BP explosion plus the following 5 trading days. Top-kill (28 May 2010 to 1 June 2010) includes the trading day before the first major attempt of BP at plugging the oil leak, the day of attempt (29 May 2010) and the trading day after. Static-kill (3 August 2010 to 5 August 2010) includes the trading day before the successful second attempt by BP to plug the leak, the day of attempt (4 August 2010) and the following trading day. Standard of error is reported in parenthesis. * refers to $5 \%$ level of significant.

\begin{tabular}{|c|c|c|c|c|}
\hline Variable Name & $\begin{array}{l}\text { Moratorium } \\
\text { Firms }(E W) \\
(n=26)\end{array}$ & $\begin{array}{l}\text { Moratorium } \\
\text { Firms }(V W) \\
(n=26)\end{array}$ & $\begin{array}{l}\text { Other Firms } \\
(E W) \\
(n=183)\end{array}$ & $\begin{array}{l}\text { Other Firms }(V W) \\
(n=183)\end{array}$ \\
\hline Intercept & $\begin{array}{l}-0.0005 \\
(0.0004)\end{array}$ & $\begin{array}{l}-0.0009^{*} \\
(0.0003)\end{array}$ & $\begin{array}{l}-0.0004 \\
(0.0004)\end{array}$ & $\begin{array}{l}-0.0007^{*} \\
(0.0003)\end{array}$ \\
\hline Market & $\begin{array}{l}1.2754 * \\
(0.0406)\end{array}$ & $\begin{array}{l}1.1126 * \\
(0.0286)\end{array}$ & $\begin{array}{c}1.0872 * \\
(0.0347)\end{array}$ & $\begin{array}{l}0.9786^{*} \\
(0.0245)\end{array}$ \\
\hline Yield curve slope & $\begin{array}{l}-0.0685 \\
(0.2983)\end{array}$ & $\begin{array}{l}-0.1732 \\
(0.2114)\end{array}$ & $\begin{array}{c}0.1402 \\
(0.2836)\end{array}$ & $\begin{array}{l}-0.0588 \\
(0.1936)\end{array}$ \\
\hline Oil futures & $\begin{array}{l}0.2639 * \\
(0.0228)\end{array}$ & $\begin{array}{l}0.1797 * \\
(0.0148)\end{array}$ & $\begin{array}{l}0.2601 * \\
(0.0193)\end{array}$ & $\begin{array}{c}0.1918^{*} \\
(0.0133)\end{array}$ \\
\hline Gas futures & $\begin{array}{l}0.0686^{*} \\
(0.0105)\end{array}$ & $\begin{array}{l}0.0250 * \\
(0.0069)\end{array}$ & $\begin{array}{l}0.0739 * \\
(0.0047)\end{array}$ & $\begin{array}{l}0.0317^{*} \\
(0.0063)\end{array}$ \\
\hline $\begin{array}{l}\text { BP Explosion } \\
(0 \text { to }+5)\end{array}$ & $\begin{array}{l}-0.0038 \\
(0.0019)\end{array}$ & $\begin{array}{l}-0.0003 \\
(0.0016)\end{array}$ & $\begin{array}{c}0.0031 \\
(0.0048)\end{array}$ & $\begin{array}{l}-0.0003 \\
(0.0020)\end{array}$ \\
\hline $\begin{array}{l}\text { TOPKILL } \\
(+28 \mathrm{TO}+30)\end{array}$ & $\begin{array}{l}-0.0141 * \\
(0.0021)\end{array}$ & $\begin{array}{l}-0.0036 \\
(0.0020)\end{array}$ & $\begin{array}{l}-0.0014 \\
(0.0021)\end{array}$ & $\begin{array}{c}0.0042 \\
(0.0024)\end{array}$ \\
\hline $\begin{array}{r}\text { STATICKILL } \\
(+74 \mathrm{TO}+76)\end{array}$ & $\begin{array}{l}0.0094 * \\
(0.0040)\end{array}$ & $\begin{array}{c}0.0052 \\
(0.0053)\end{array}$ & $\begin{array}{c}0.0007 \\
(0.0064)\end{array}$ & $\begin{array}{c}0.0044 \\
(0.0034)\end{array}$ \\
\hline $\mathrm{C}$ & $\begin{array}{c}0.0000 \\
(0.0000)\end{array}$ & $\begin{array}{c}0.0000 \\
(0.0000)\end{array}$ & $\begin{array}{l}0.0000^{*} \\
(0.0000)\end{array}$ & $\begin{array}{c}0.0000 \\
(0.0000)\end{array}$ \\
\hline $\operatorname{RESID}(-1)^{\wedge} 2$ & 0.0227 & 0.0182 & $-0.0296^{*}$ & 0.0214 \\
\hline
\end{tabular}




\begin{tabular}{l|cccc}
\hline & $(0.0153)$ & $(0.0144)$ & $(0.0058)$ & $(0.0153)$ \\
GARCH(-1) & $0.9624^{*}$ & $0.9653^{*}$ & $1.0190^{*}$ & $0.9653^{*}$ \\
& $(0.0176)$ & $(0.0184)$ & $(0.0061)$ & $(0.0196)$ \\
\hline Adj-Rsquare & 0.8494 & 0.8790 & 0.8539 & 0.8844 \\
S.E of regression & 0.0095 & 0.0067 & 0.0085 & 0.0060 \\
\hline
\end{tabular}




\section{A. Appendix}

\section{Table A.1 Important dates}

\begin{tabular}{|c|c|c|}
\hline Event & $\begin{array}{l}\text { Event date or event period } \\
\text { used in analysis }\end{array}$ & Details \\
\hline BP explosion & 22 April 2010 & $\begin{array}{l}\text { The day of the official BP announcement } \\
\text { regarding the well explosion. The actual } \\
\text { explosion occurred on the } 20 \text { April } 2010 \\
\text { though there was little evidence of market } \\
\text { reaction until the official announcement on the } \\
22 \text { April } 2010 \text {. }\end{array}$ \\
\hline BP explosion $(0$ to +5$)$ & $\begin{array}{l}22 \text { April } 2010 \text { to } 29 \text { April } \\
2010\end{array}$ & $\begin{array}{l}\text { BP explosion plus the following } 5 \text { trading } \\
\text { days }\end{array}$ \\
\hline Pre-moratorium & $\begin{array}{l}25 \text { May } 2010 \text { to } 26 \text { May } \\
2010\end{array}$ & $\begin{array}{l}\text { The two trading days before the introduction } \\
\text { of the first moratorium }\end{array}$ \\
\hline Moratorium & 27 May 2010 to 1 June 2010 & $\begin{array}{l}\text { The day the first moratorium was announced } \\
\text { ( } 27 \text { May 2010) and the following two trading } \\
\text { days }\end{array}$ \\
\hline Top-kill & 28 May 2010 to 1 June 2010 & $\begin{array}{l}\text { The trading day before the first major attempt } \\
\text { of BP at plugging the oil leak, the day of } \\
\text { attempt ( } 29 \text { May 2010) and the trading day } \\
\text { after. }\end{array}$ \\
\hline $\begin{array}{l}\text { President Obama's } \\
\text { statement and BP } \\
\text { response }\end{array}$ & 9 June 2010 to 10 June 2010 & $\begin{array}{l}\text { The day of President Obama's statement and } \\
\text { BP's response concerning responsibility for } \\
\text { the incident the follow day }\end{array}$ \\
\hline Pre-overruling & $\begin{array}{l}18 \text { June } 2010 \text { to } 21 \text { June } \\
2010\end{array}$ & $\begin{array}{l}\text { The two trading days before the moratorium } \\
\text { overruling was announced }\end{array}$ \\
\hline Overruling & $\begin{array}{l}\text { 22 June } 2010 \text { to } 24 \text { June } \\
2010\end{array}$ & $\begin{array}{l}\text { The day of the overruling of the moratorium } \\
\text { (22 June 2010) and the following two trading } \\
\text { days }\end{array}$ \\
\hline Pre-moratorium 2 & 8 July 2010 to 9 July 2010 & $\begin{array}{l}\text { The two trading days before the introduction } \\
\text { of the second moratorium }\end{array}$ \\
\hline Moratorium 2 & 12 July 2010 to 14 July 2010 & $\begin{array}{l}\text { The day of moratorium (12 July 2010) and the } \\
\text { two following trading days }\end{array}$ \\
\hline Static-kill & $\begin{array}{l}3 \text { August } 2010 \text { to } 5 \text { August } \\
2010\end{array}$ & $\begin{array}{l}\text { The trading day before the successful second } \\
\text { attempt by BP to plug the leak, the day of } \\
\text { attempt ( } 4 \text { August 2010) and the following } \\
\text { trading day }\end{array}$ \\
\hline
\end{tabular}




\section{References}

Ball R and Brown P (1968) An empirical evaluation of accounting income numbers. Journal of Accounting Research 6(2): 159-178.

Blose LR, Bornkamp R, Brier M, et al. (1996) Catastrophic events, contagion, and stock market efficiency: The case of the space shuttle Challenger. Review of Financial Economics 5(2): 117-129.

Bowen RM, Castanias RP and Daley LA (1983) Intra-industry effects of the accident at Three Mile Island. Journal of Financial and Quantitative Analysis 18(1): 87-111. Boyer MM and Filion D (2007) Common and fundamental factors in stock returns of Canadian oil and gas companies. Energy Economics 29(3): 428-453.

Brown JR, Cummins JD, Lewis CM, et al. (2004) An empirical analysis of the economic impact of federal terrorism reinsurance. Journal of Monetary Economics 51(5): 861-898.

Cable J and Holland K (2000) Robust vs. OLS estimation of the market model: Implications for event studies. Economics Letters 69(3): 385-391.

Capelle-Blancard G and Laguna M-A (2010) How does the stock market respond to chemical disasters? Journal of Environmental Economics and Management 59(2): 192205.

Chari VV (2004) Comment on : "An empirical analysis of the economic impact of federal terrorism reinsurance". Journal of Monetary Economics 51(5): 899-902. Choi JS, Kwak YM and Choe C (2010) Corporate social responsibility and corporate financial performance: Evidence from Korea. Australian Journal of Management 35(3): 291-311.

Coutts JA, Mills TC and Roberts J (1994) The market model and the event study method: A synthesis of the econometric criticisms. International Review of Financial Analysis 3(2): 149-171.

Cummins J D, Lewis CM and Wei R (2006) The market value impact of operational loss events for us banks and insurers. Journal of Banking and Finance 30(10): 26052634.

Dekel E and Scotchmer S (1990) Collusion through insurance: Sharing the cost of oil spill cleanups. American Economic Review 80(1): 249-252.

Doherty NA, Lamm-Tennant J and Starks LT (2003) Insuring September 11th: Market recovery and transparency. Journal of Risk and Uncertainty 26(2): 179-199.

Eilperin J (2010) Independent probe of oil spill in the works. The Washington Post, 18 May. Available at: www.washingtonpost.com.

El-Sharif I, Brown D, Burton B, et al. (2005) Evidence on the nature and extent of the relationship between oil prices and equity values in the UK. Energy Economics 27(6): 819-830. 
Fama EF, Fisher L, Jensen MC, et al. (1969) The adjustment of stock prices to new information. International Economic Review 10(1): 1-21.

Fink JD, Fink KE and Russell A (2010) When and how do tropical storms affect markets? The case of refined petroleum. Energy Economics 32(6): 1283-1290. Fodor A and Stowe JD (2010) The BP Oil Disaster: Stock and Option Market Reactions. Available at: $\underline{\text { ssrn.com/abstract }=1631970}$

Friedman HH and Friedman LW (2010) Lessons from the Twin Mega-Crises: The Financial Meltdown and the BP Oil Spill. Available at: ssrn.com/abstract=1654596. Froot KA (2001) The market for catastrophe risk: A clinical examination. Journal of Financial Economics 60(2-3): 529-571.

Garcia-Castro R, Ariño M and Canela M (2010) Does social performance really lead to financial performance? Accounting for endogeneity. Journal of Business Ethics 92(1): 107-126.

Garmaise MJ and Moskowitz TJ (2009) Catastrophic risk and credit market. Journal of Finance 64(2): 657-707.

Gupta S and Goldar B (2005) Do stock markets penalize environment-unfriendly behaviour? Evidence from india. Ecological Economics 52(1): 81-95.

Hill J and Schneeweis T (1983) The effect of Three Mile Island on electric utility stock prices: A note. Journal of Finance 38(4): 1285-1292.

Jin Y and Jorion P (2006) Firm value and hedging: Evidence from oil and gas producers. Journal of Finance 61(2): 893-919.

Kalra R, Henderson GV and Raines GA (1993) Effects of the Chernobyl nuclear accident on utility share prices. Quarterly Journal of Business and Economics 32(1): 52-77.

Laplante B and Lanoie P (1994) The market response to environmental incidents in Canada: A theoretical and empirical analysis. Southern Economic Journal 60(3): 657672.

Leahy M and Eilperin J (2010) How politics spilled into policy. The Washington Post, 12 October. Available at: www.washingtonpost.com.

Lee DD, Faff RW and Langfield-Smith K (2009) Revisiting the vexing question: Does superior corporate social performance lead to improved financial performance?

Australian Journal of Management 34(1): 21-49.

Lorraine NHJ, Collison DJ and Power DM (2004) An analysis of the stock market impact of environmental performance information. Accounting Forum 28(1): 7-26.

Maloney MT and Mulherin JH (2003) The complexity of price discovery in an efficient market: The stock market reaction to the Challenger crash. Journal of Corporate Finance 9(4): 453-479.

Mansur I, Cochran SJ and Phillips JE (1991) The relationship between the equity return levels of oil companies and unanticipated events: The case of the Exxon Valdez accident. Logistics and Transportation Review 27(3): 241-255. 
Mitchell MT and Mulherin JH (1994) The impact of public information on the stock market. Journal of Finance 49(3): 923-950.

Muoghalu MI, Robinson HD and Glascock JL (1990) Hazardous waste lawsuits, stockholder returns, and deterrence. Southern Economic Journal 57(2): 357-370.

Nandha M and Faff R (2008) Does oil move equity prices? A global view. Energy Economics 30(3): 986-997.

Ramos SB and Veiga H (2011) Risk factors in oil and gas industry returns: International evidence. Energy Economics 33(3): 525-542.

Sadorsky P (2001) Risk factors in stock returns of Canadian oil and gas companies. Energy Economics 23(1): 17-28. 